\title{
STUDIES OF COPROPORPHYRIN. II. AN INVESTIGATION OF THE CONTRIBUTION TO THE URINARY COPROPORPHYRIN OF HEMOGLOBIN AND OF BACTERIAL METABOLISM IN THE INTESTINAL TRACT ${ }^{1,2}$
}

\author{
By EVREL A. LARSON ANd CECIL JAMES WATSON
}

(From the Department of Medicine, University of Minnesota Hospital, Minneapolis)

(Received for publication July 9, 1948)

Stokvis (1) advanced the idea that blood in the intestinal tract was the source of the urinary porphyrin. Schumm (2) also held this belief. Subsequent studies, notably those of Fischer and Hilmer (3), Brugsch $(4,5)$, and Kaunitz (6) indicated that a variable fraction of the urinary coproporphyrin was thus derived. The presence of a porphyrin in meconium $(2,7,8)$, later identified by Waldenström as coproporphyrin I (9), together with a number of other evidences of an endogenous formation, which are discussed in detail in recent reviews $(10,11)$, have made it rea- sonably clear that at most not more than a certain fraction of the, urinary coproporphyrin (UCP) could be regarded as originating in the intestinal tract. The purpose of the present investigation was to obtain more definite information as to the size of this fraction, under various experimental and clinical conditions. It was also determined to study the relative percentage of coproporphyrin isomers composing any increases which might be observed, since previous studies bearing on these questions had dealt only with the total coproporphyrin. It was conceivable on a priori reasoning, that any one or a combination of the following might alter the total coproporphyrin concentration or the isomer distribution in the urine:

(1) A formation of coproporphyrin III from hemoglobin, by the bacterial flora of the colon, with reabsorption and excretion in the urine. Jakob (12) showed that pure cultures of $E$. coli produce small amounts of coproporphyrin III in the presence of hemoglobin. Snapper (13-15)

1 Aided by grants from the John and Mary R. Markle Foundation, New York City, and the Medical Research Fund of the Graduate School, University of Minnesota, Minneapolis.

2 A portion of this study was included in a thesis submitted (by E. A. L.) in partial fulfillment of the requirements for the Ph.D. degree, University of Minnesota. had previously shown that hemoglobin is converted in small part to protoporphyrin in the colon, and Kämmerer (16) ascribed its formation to a symbiotic activity of the bacterial flora. Hill and Holden (17) showed, however, that pure cultures of $E$. coli liberated free protoporphyrin from hemoglobin; this was confirmed by van den Bergh and co-workers (18). No direct evidence has been described, however, for the intestinal formation of coproporphyrin III from hemoglobin, although the above-mentioned work of Jakob's suggested that this might take place. In a previous study (19), it was shown that in the presence of complete biliary obstruction due to cancer, coproporphyrin could not be demonstrated in the acholic feces even when there was bleeding into the upper gastrointestinal tract. This observation does not favor an origin from hemoglobin in the bowel, but the possibility could not be excluded that coproporphyrin thus formed had been entirely reabsorbed.

(2) A formation of coproporphyrin, either I or III, as an independent bacterial synthesis in the absence of hemoglobin. Fischer and co-workers $(3,20)$ demonstrated that yeast cells undergoing autolysis, synthesize coproporphyrin I. Kench and Wilkinson (21) have recently shown that yeast cells elaborate both isomers, the preponderance depending on the conditions of the culture. Coulter and Stone (22) found that diphtheria bacilli in broth cultures form coproporphyrin in an amount roughly proportional to that of the toxin produced. Gray and Holt (23) have recently demonstrated that this is the type III isomer and that it is formed in relatively large amount under suitable conditions of growth. All of these observations suggested that the bacterial flora of the human colon might, at least under certain circumstances, produce either coproporphyrin I or III, and, if it were absorbed, might thus bring 
about an increased urinary excretion of the corresponding isomer. von Mallinkrodt-Haupt (24) has, in fact, postulated that the urinary coproporphyrin is wholly related to the bacterial flora in the colon, and that the increases described in pernicious anemia are related to the effect of achylia in altering the flora. It will be seen subsequently that the evidence in favor of this theory is indeed very meager.

(3) The further possibility had to be considered that liver function plays an important role with respect to coproporphyrin I or III, which might originate in the intestinal tract whether from hemoglobin or bacterial metabolism. Kaunitz' study (6) suggested that coproporphyrin is absorbed from the intestine but that it does not appear in the urine in appreciable amount unless there is associated liver functional impairment. Thus, after oral administration of $20 \mathrm{Gm}$. doses of crystalline hemoglobin, significant increases of urinary coproporphyrin were observed only in cases of liver disease, or in instances where liver injury was postulated as a result of severe anemia or toxemia. Kaunitz assumed but did not prove that the increases which he noted were composed of type III isomer, derived from the fed hemoglobin. Kaunitz (6) and Boas $(25,26)$ described increases of urinary coproporphyrin following gastrointestinal bleeding due to peptic ulcer or malignancy. This increase was likewise assumed to be composed of the type III isomer, although it was not isolated. There is also the possibility that some degree of liver functional impairment had occurred with resultant increase of type I rather than type III, an association which has been discussed previously (11), and in favor of which there is abundant evidence in the literature $(5,10,27-29)$. It seems less probable, however, that this factor would be important after the simple ingestion of blood by normal individuals, which was reported by Schumm (2), and Fischer (3) to be followed by an increased urinary coproporphyrin of undetermined type. This was not confirmed by other investigators $(14,15,30,31)$, nor were Borst and Königsdörffer (32) able to detect the appearance of any porphyrin in the blood plasma after ingestion of coproporphyrin.

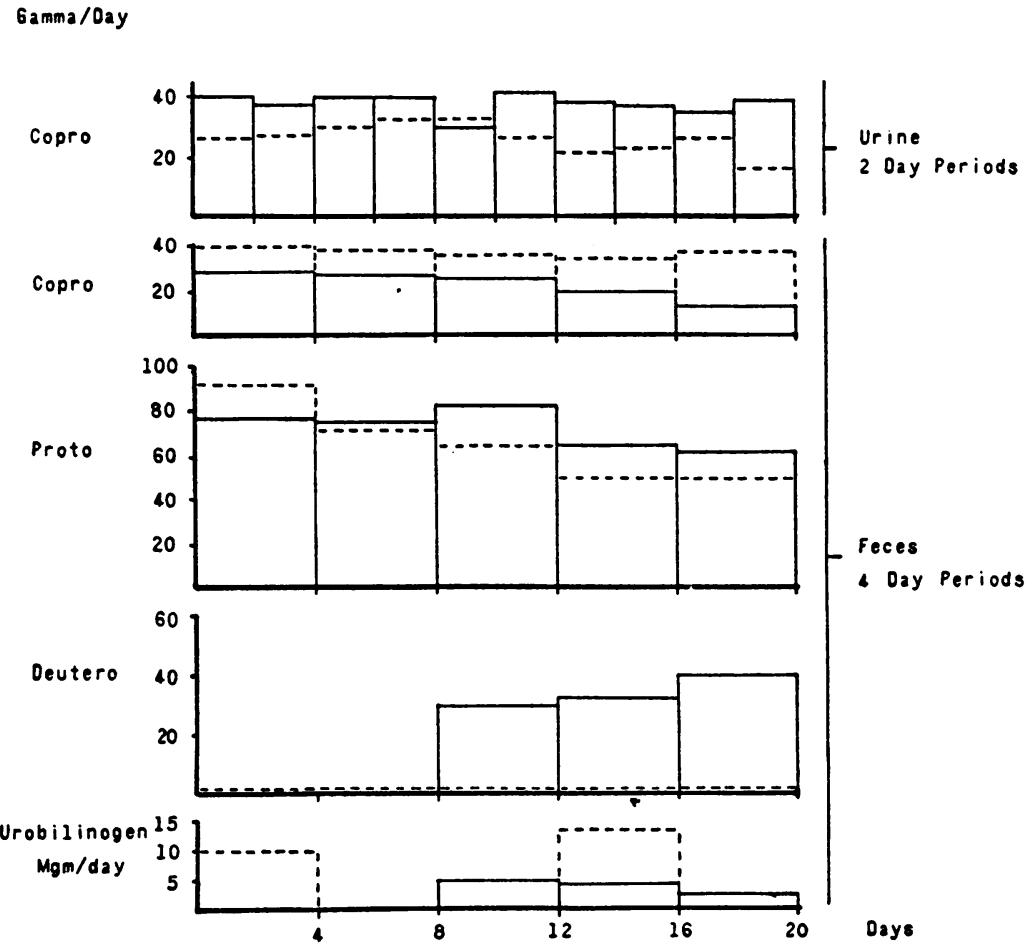

Fig. 1. Normal Excretion of Porphyrin in Dogs

Dog No. 1 : Solid lines; diet-milk.

Dog No. 2: Broken lines; diet-“kibbled" dog food and milk. 


\section{MATERIAL AND METHODS}

In view of the above considerations, the present study was planned as outlined in the following:

I. Studies on dogs.

A. Feeding of blood-two dogs.

B. Feeding of raw meat-two dogs.

II. Studies on human subjects.

A. Cases having blood in the gastrointestinal tract due either to hemorrhage or to feeding of blood:

Hemorrhagic gastritis, one case; malnutrition, one case; hepatic gumma, one case; bacterial endocarditis, one case; cholecystitis and cholelithiasis, three cases; infectious hepatitis (recovery phase), one case; carcinoma of head of pancreas, one case; cirrhosis and chronic alcoholism, two cases; idiopathic cirrhosis, one case.

B. Feeding of crystalline coproporphyrins:

1) Type III isomer-3-5 mgm. orally.

Bacterial endocarditis, one case; cholecystitis and cholelithiasis, one case; acute alcoholism, one case; active duodenal ulcer without hemorrhage, one case; cirrhosis and chronic alcoholism, one case.

2) Type I isomer $-3 \mathrm{mgm}$. orally.

Cirrhosis and chronic alcoholism, one case.

Diet

Gamma/Day

Copro

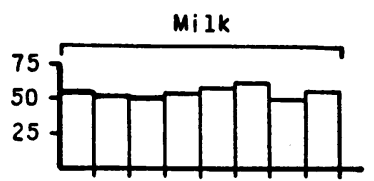

Copro

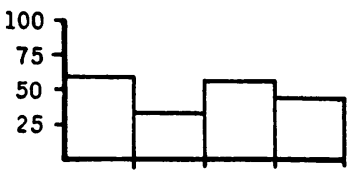

Proto

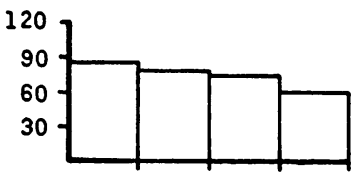

Deutero
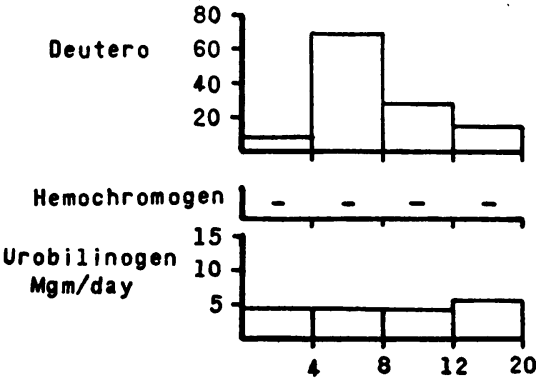

The method used for determining coproporphyrin in the urine, both total and isomer distribution, was that of Schwartz and co-workers (33). The method for the feces was that described by Watson and Layne (34). This is not an exact procedure but permits a rough approximation of the three main types of porphyrins found in the feces: 1) coproporphyrin, 2) protoporphyrin, 3 ) deutero- and the pseudo-deuteroporphyrins (19). The animals used were shepherd dogs, weighing $20-30$ pounds, housed in standard metabolism cages which were so constructed that the urine could be collected quantitatively under a small amount of toluene preservative. During the control period, one dog was maintained on a strict milk diet, productive of marked constipation, the other on a diet of "kibbled dog food" and milk, with which the bowel movements were normal. The urine coproporphyrin determination was carried out every two days. As mentioned previously, coproporphyrin does not deteriorate significantly in this period of time. In the human experiments determinations were made on 24 hour samples of urine. The feces porphyrins in both dogs and humans were determined on four-day collections. Urobilinogen was determined by Watson's modification (35) of Terwen's method (36). Porphyrin isolations and melting point determinations were carried out according to previously described methods $(19,37,38,39)$. The total heme pigments of the feces were determined by the method of Flink and Watson (40). The crystalline

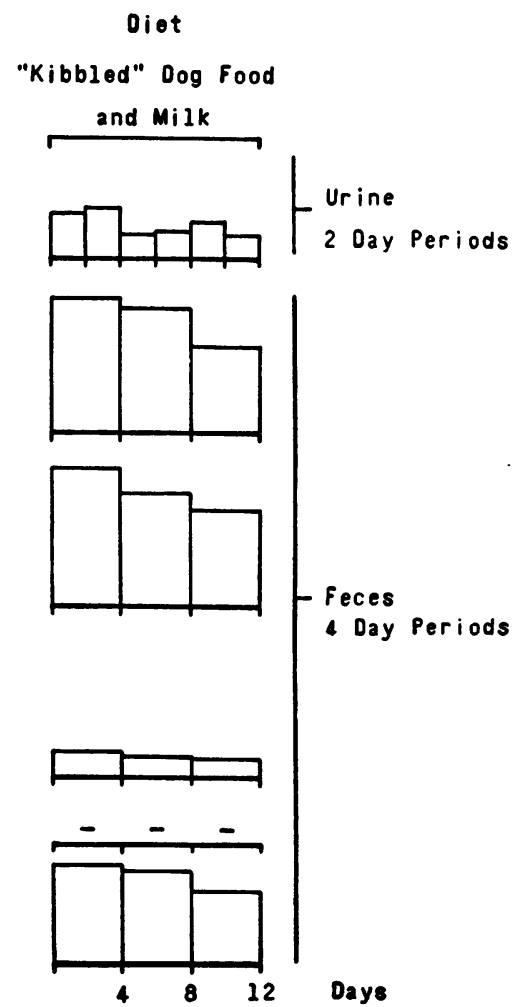

Fig. 2. Effect of Dietary Change upon the Porphyrin Excretion Dog No. 1. 


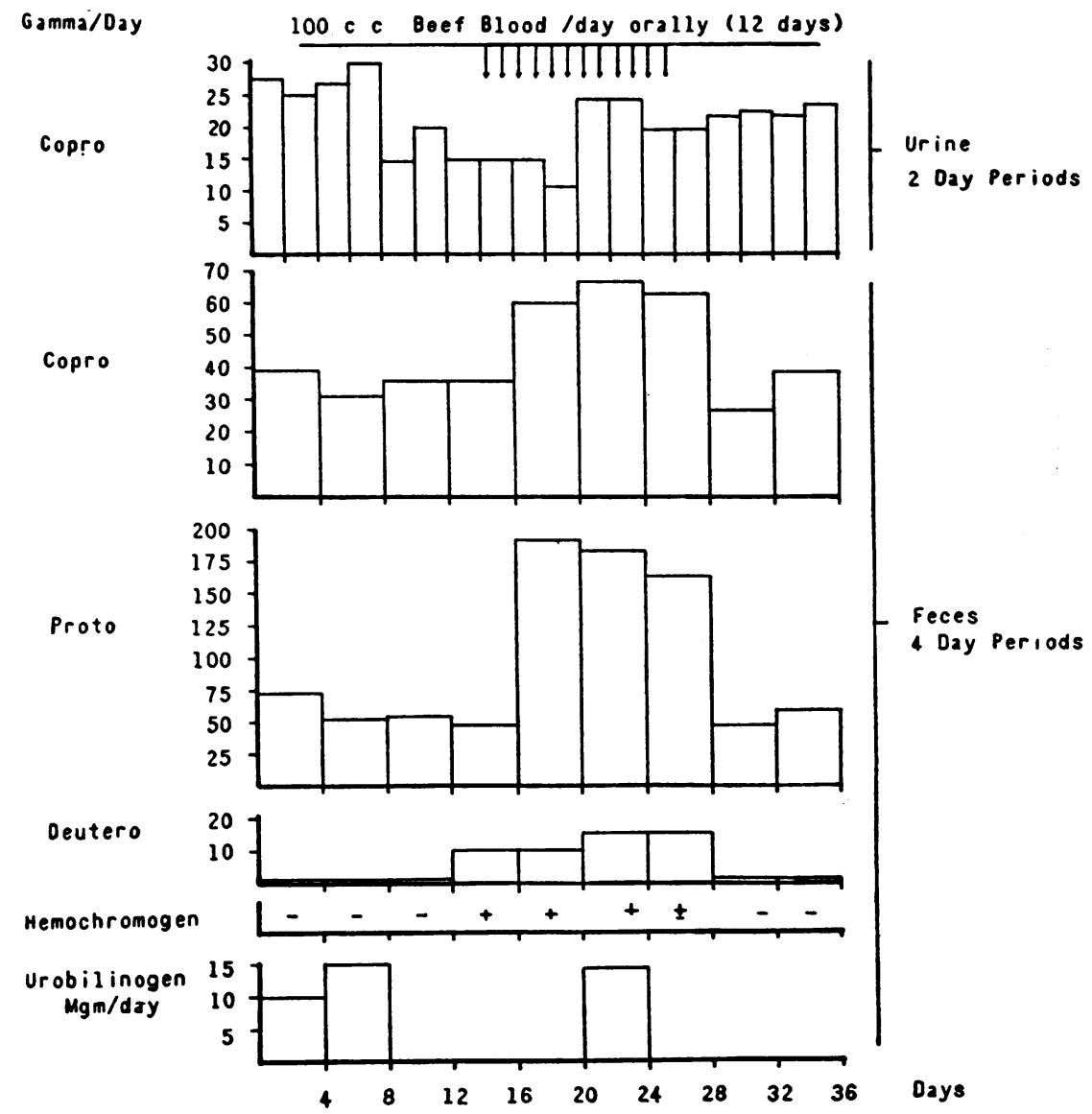

Fig. 3. Effect of Ingested Blood upon the Porphyrin Excretion in Dogs Dog No. 2; diet-“kibbled" dog food and milk.

coproporphyrins were fed as the hydrochlorides in a weakly acid solution. The diet was meat-free only in the cases indicated in Table $\mathrm{I}$.

E. coli, Aerobacter aerogenes, Pseudomonas aeruginosa, and, in one instance, an inoculum of feces were utilized in studies of the in vitro synthesis of porphyrin by bacteria. The media employed were nutrient broth and tryptose broth, the same media with $5 \%$ citrated human blood added, and a synthetic medium of the Gladstone type. The periods of growth are indicated in Table II. The method of porphyrin extraction and separation in these experiments was similar to that used for the feces, save for the preliminary acetic ether extract of the liquid media. A spectrophotometric method was used in attempting to demonstrate heme pigments in plain broth (40).

\section{RESULTS}

Dog No. 1 (strict milk diet) excreted more urinary and less fecal coproporphyrin than dog No. 2 ("kibbled" dog food and milk) (Figure 1). On being changed from a milk diet to a diet of "kibbled" dog food and milk, dog No. 1 showed a significant alteration in porphyrin excretion, i.e., a decrease in urine and an increase in the feces. The total amount excreted, however, remained approximately the same (Figure 2 ). This interesting change will be considered subsequently. The porphyrin excretion by dogs No. 1 and No. 2 following the feeding of blood and of raw, red meat is shown in Figures 3 and 4 . No significant increases in the UCP were observed after feeding blood (Figure 3).

Figure 4, which shows the effect of feeding washed, raw, red meat to dog No. 2 , is also believed to be representative of experience gained in another similar study. At first glance, it might appear that the dog excreted increased amounts of urinary porphyrin following addition of meat to the diet. However, this increase was indeed slight and was maintained long after the meat was 

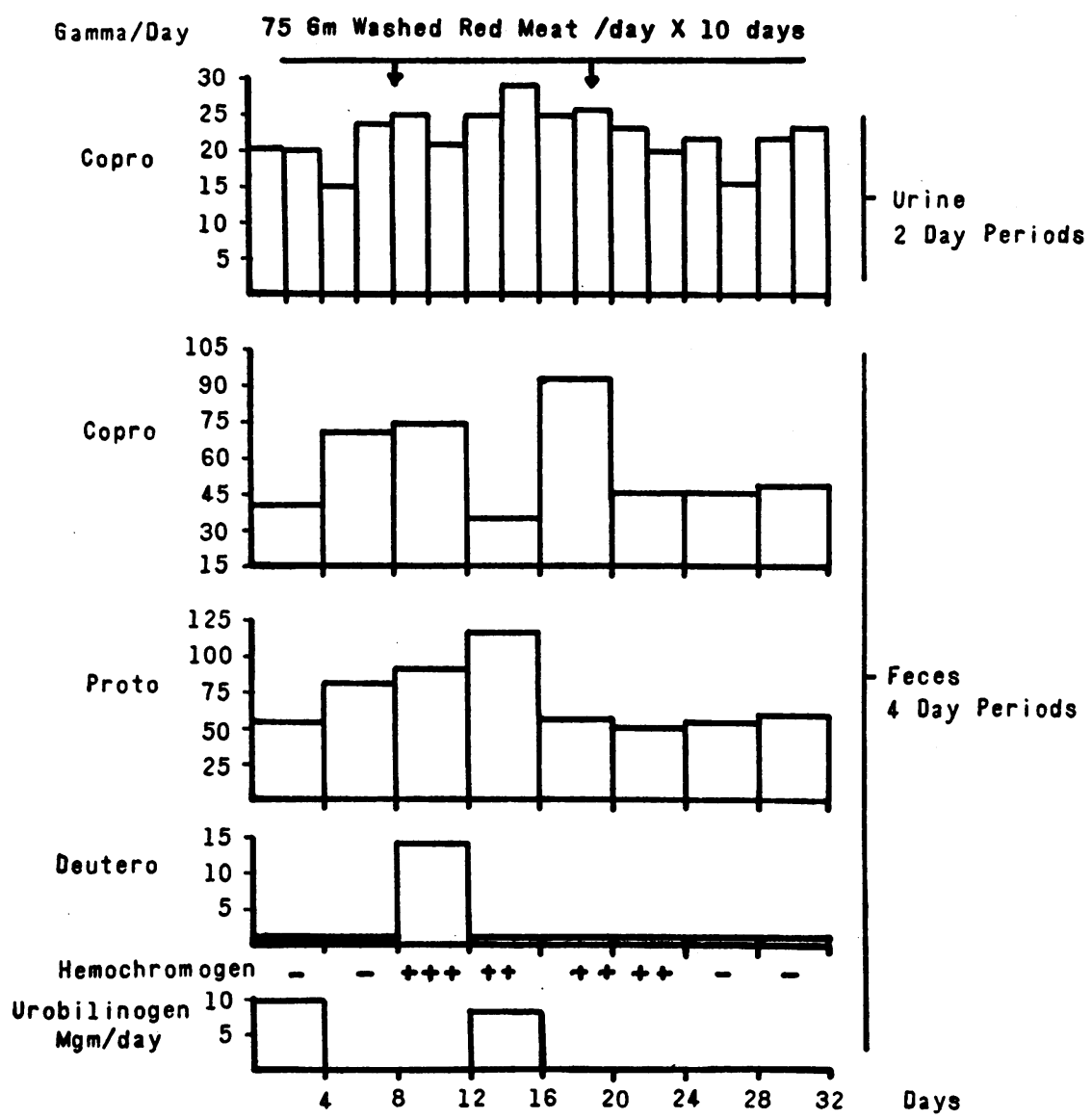

Fig. 4. Effect of Ingested Raw Meat upon the Porphyrin Excretion in Dogs Dog No. 2; diet-"kibbled" dog food and milk.

discontinued; this may represent nothing more than a normal variation in excretion by the animal, a finding repeatedly demonstrated during the course of the dog experiments. Furthermore, the coproporphyrin methyl ester isolated from the urine during the control period and during meat feeding melted at $246^{\circ} \mathrm{C}$. Since this is the type I isomer, it appears unlikely that any appreciable increase had been derived from the heme pigments of the fed meat. The findings in the feces of the two dogs following the feeding of both blood and raw meat, of which Figures 3 and 4 are representative, were quite similar. Increases in all three fractions were observed. The coproporphyrin of the feces after meat feeding was identified as the type $I$ isomer in dog No. 2. The presence of small amounts of coproporphyrin III was strongly suggested by a highly colored mother liquor following crystallization of the type $I$ isomer, but further crystallization could not be effected.

Figures 5, 6, and 7 show the results of studies on several human subjects following the feeding of hemoglobin, coproporphyrin III, and in one instance, coproporphyrin I (Figure 5). Except where otherwise indicated, the studies were conducted in consecutive four-day periods. The results of studies on a 59 year old patient having outspoken evidence of cirrhosis and severe hepatic functional impairment associated with chronic alcoholism and dietary deficiency, are shown in Figure 5. Although the average excretion of urinary porphyrin is slightly greater after the feeding of hemoglobin, the occurrence of gross variations during the control period and in previous untabulated determinations, minimizes the significance of this increase. Moreover, the unexplained decrease 
in the next four-day period, following the feeding of $5 \mathrm{mgm}$. of coproporphyrin III, is probably a further coincidental variation in excretion. The low values after $3 \mathrm{mgm}$. of coproporphyrin I were obtained during a later period, when the average urinary excretion was appreciably lower than that observed early in the patient's hospital course. Of principal importance is the fact that during both feeding experiments, approximately all of the fed coproporphyrin appeared in the feces and there was no increase in the urine. In one instance after the feeding of coroporphyrin III, the same isomer was easily crystallized and identified from the feces. Figure 6 shows the results of studies on a 62 year old woman with a high-grade biliary obstruction due to an impacted common duct stone. An increase in the urinary porphyrin excretion was observed on the third day following hemoglobin feeding, but during the corresponding fourday period, there was a diminished fecal coproporphyrin excretion, suggesting an increased ob- struction to bile flow. There was no increase in urinary porphyrin excretion following the feeding of coproporphyrin III, most of which was accounted for in the feces. Further data on jaundiced subjects are shown in Figure 7: Case 12 (cirrhosis), Case 13 (calculus obstruction), and Case 14 (carcinomatous obstruction). The results of additional case studies are listed in Table I.

Case 2 (Table I) requires further explanation. This individual had taken alcohol rather continuously until the hour of admission in spite of epigastric pain and moderate hematemesis. The diet had been deficient for a matter of months prior to this time. The results of the study appear to indicate that significantly larger amounts of coproporphyrin were excreted in the urine while blood was present in the bowel. However, the "control" study, following cessation of bleeding, was conducted eight days later, when the patient was in a far better nutritional state and had not been drink-

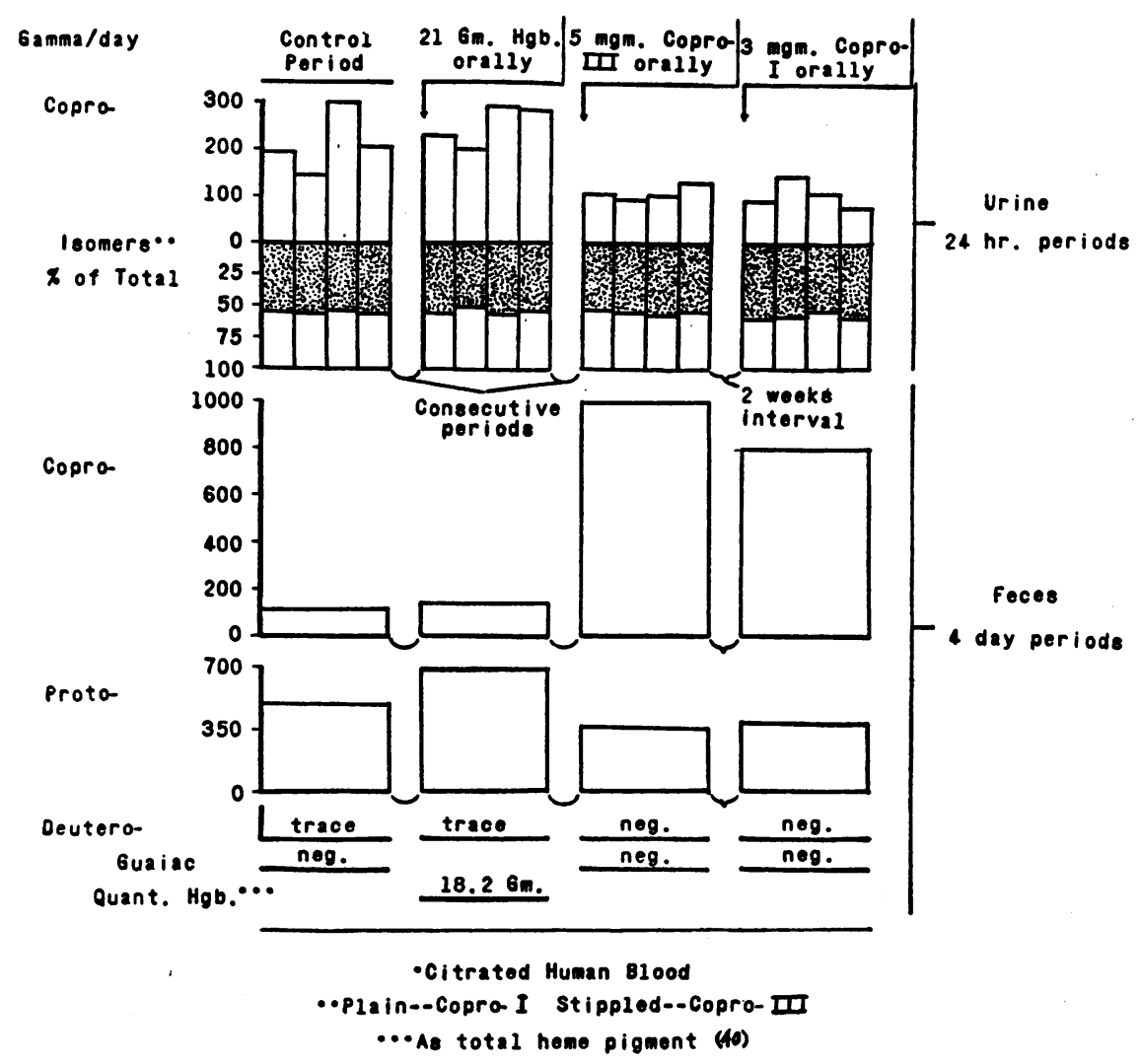

Fig. 5. Effect of the Ingestion of Hemoglobin and of Coproporphyrin III ANd I upon the Porphyrin Excretion in the Presence of Severe Liver Damage 


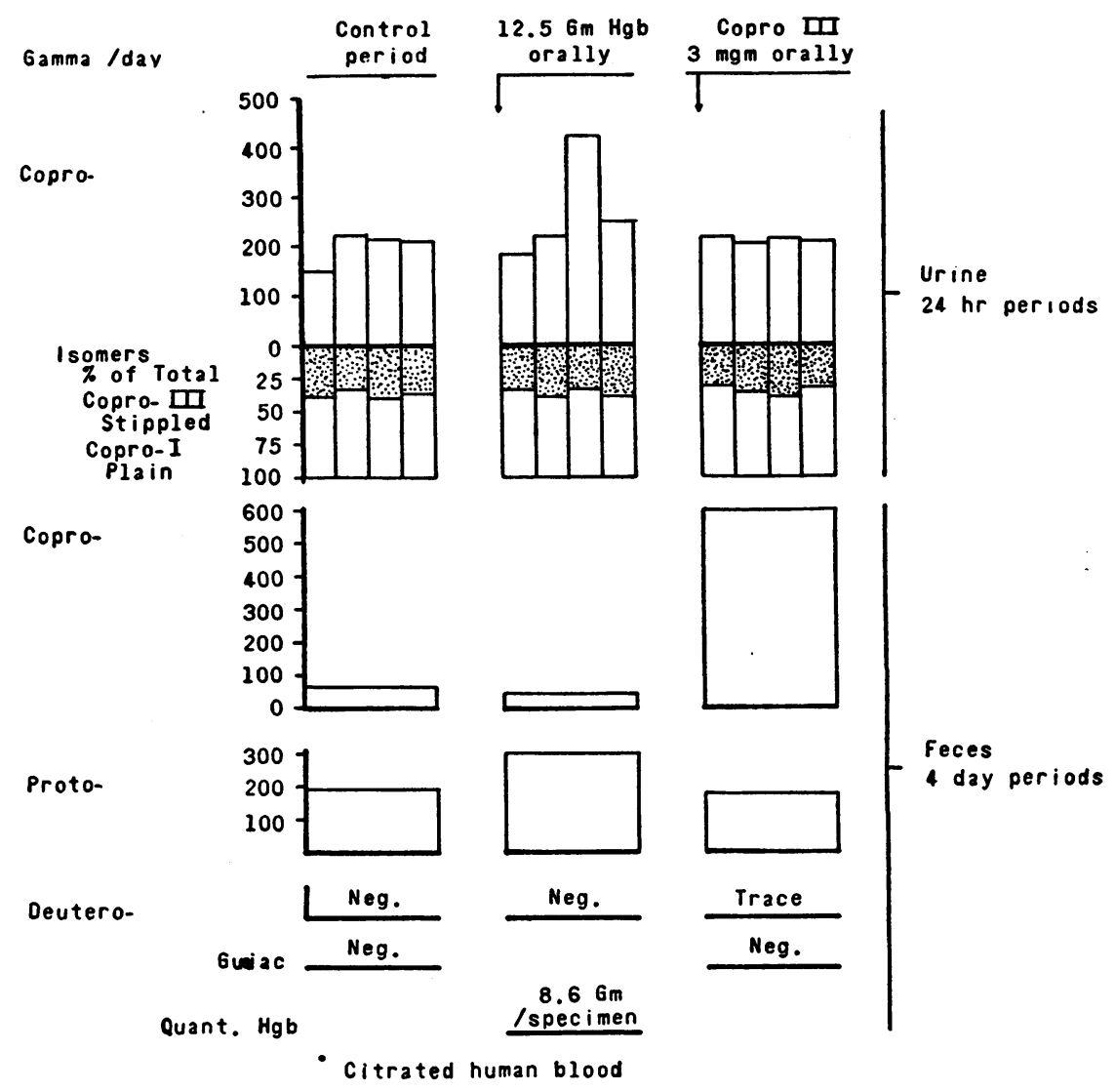

Fig. 6. Effect of Oral Hemoglobin and Coproporphyrin III upon the Porphyrin EXCRETION IN Humans

ing. The effect of acute alcoholism upon the urinary porphyrin excretion is shown in Case 7, Table I, and will be discussed in detail in a subsequent paper of this series.

The results of studies of the synthesis of porphyrins by bacteria are shown in Table II.

\section{DISCUSSION}

The results of the studies on dogs maintained on different diets appear to permit either of two interpretations: (1) That the constipating effect of a milk diet promotes absorption of coproporphyrin from the bowel and consequent increase in urinary excretion; or (2) That the excretory function of the liver is relatively sluggish on a milk diet with the result that a larger fraction of the total appears in the urine. Since it would appear that a normal liver might be expected to handle the increment of coproporphyrin which an enterohepatic circulation due to constipation might conceivably provide, we are inclined to favor the second of these two interpretations. It is quite possible that the bile flow is a major factor in the difference between the two diets; there is reason to believe that less bile would be formed on the milk diet alone because of its relatively higher carbohydrate, and lower protein content $(3.5 \%$ as against $22.5 \%$ ), and hence that less coproporphyrin might be excreted by the liver.

No conclusive evidence was obtained in the dogs of a process of reabsorption and increased excretion of coproporphyrin in the urine following the feeding of blood or meat. The increase of fecal coproprophyrin excretion observed in each animal in these experiments is probably related to an increased flow of bile, although a bacterial synthesis cannot be excluded. The finding that this increase is represented by the type I rather than the type III isomer favors the former rather than the latter possibility, since the coproporphyrin of 
the bile has been shown to be type $I$, while the preexisting evidence and that furnished by the present study indicate that bacteria elaborate type III.

The more detailed studies in human subjects also fail to furnish any conclusive evidence for a reabsorption of porphyrin from the bowel following the feeding of blood, regardless of the state of liver function. Moreover, the excretion of urinary porphyrin after the feeding of coproporphyrin III in five instances and of the type $I$ isomer in one instance actually provides significant evidence to the contrary. Although these findings are at variance with those of Kaunitz and others after the feeding of hemoglobin or blood $(3,6)$ and coproporphyrin I (3), they are strongly supported in the present investigation by the observation that the relative percentages of isomer types did not change. This finding practically excludes any appreciable contribution to the UCP of fed protoporphyrin type III (hemoglobin) or coproporphyrin III and I. Any increase in urinary coproporphyrin excretion following the feeding of either porphyrin would necessarily be of the same type. This assumption is based on chemical evidence that a transformation of one type of isomer to another would entail a disruption and complete resynthesis of the molecule. Although quantitative recoveries were seldom attained, it was obvious that the bulk of the fed porphyrin could be found in the following fourday collection of feces.

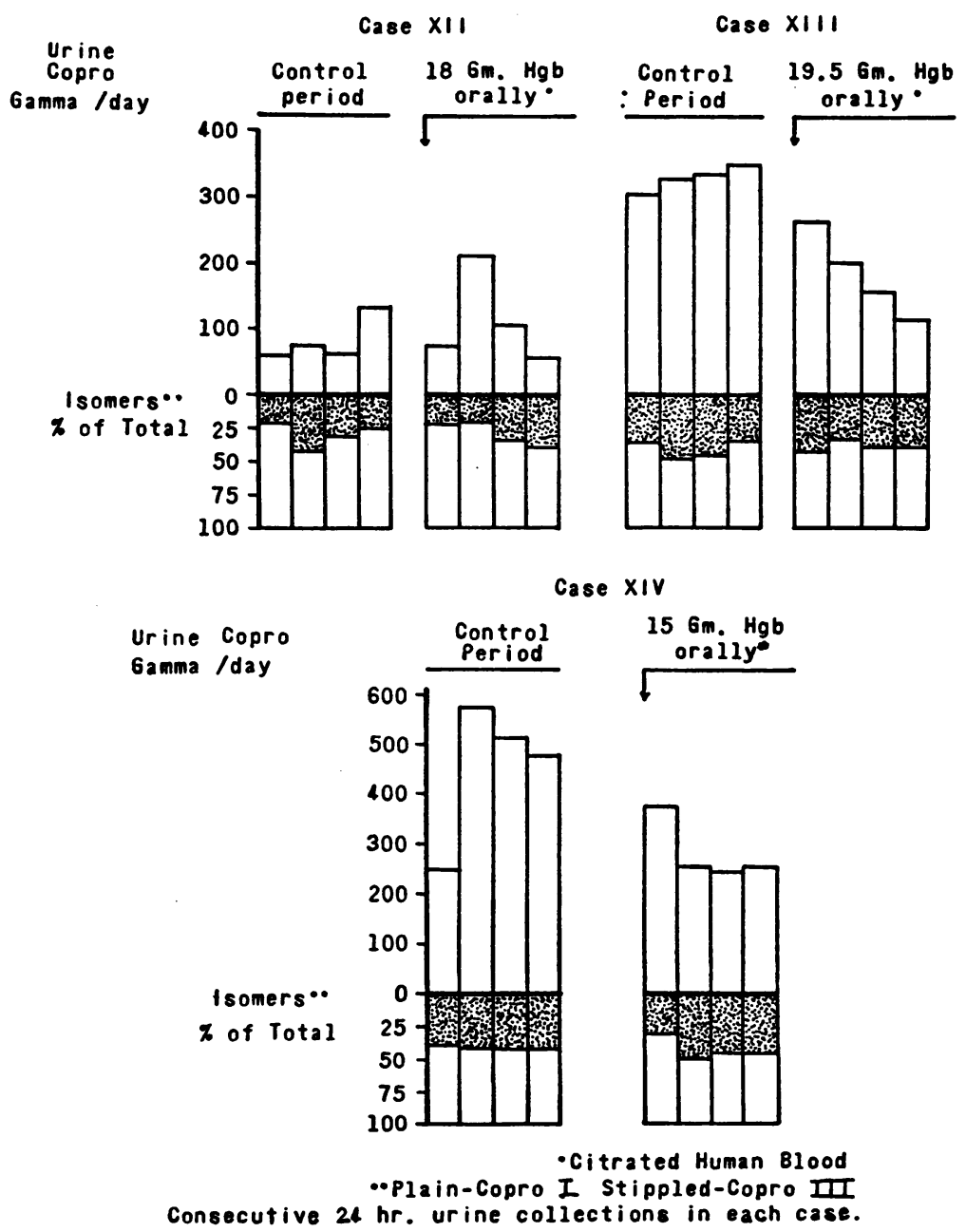

Fig. 7. EFfect of THE INGestion of Hemoglobin UPON THE URINARY Porphyrin Excretion in the Presence of Severe Liver Damage (Case 12) and of Obstructive Jaundice (Cases 13 and 14) 
EVREL A. LARSON AND CECIL JAMES WATSON

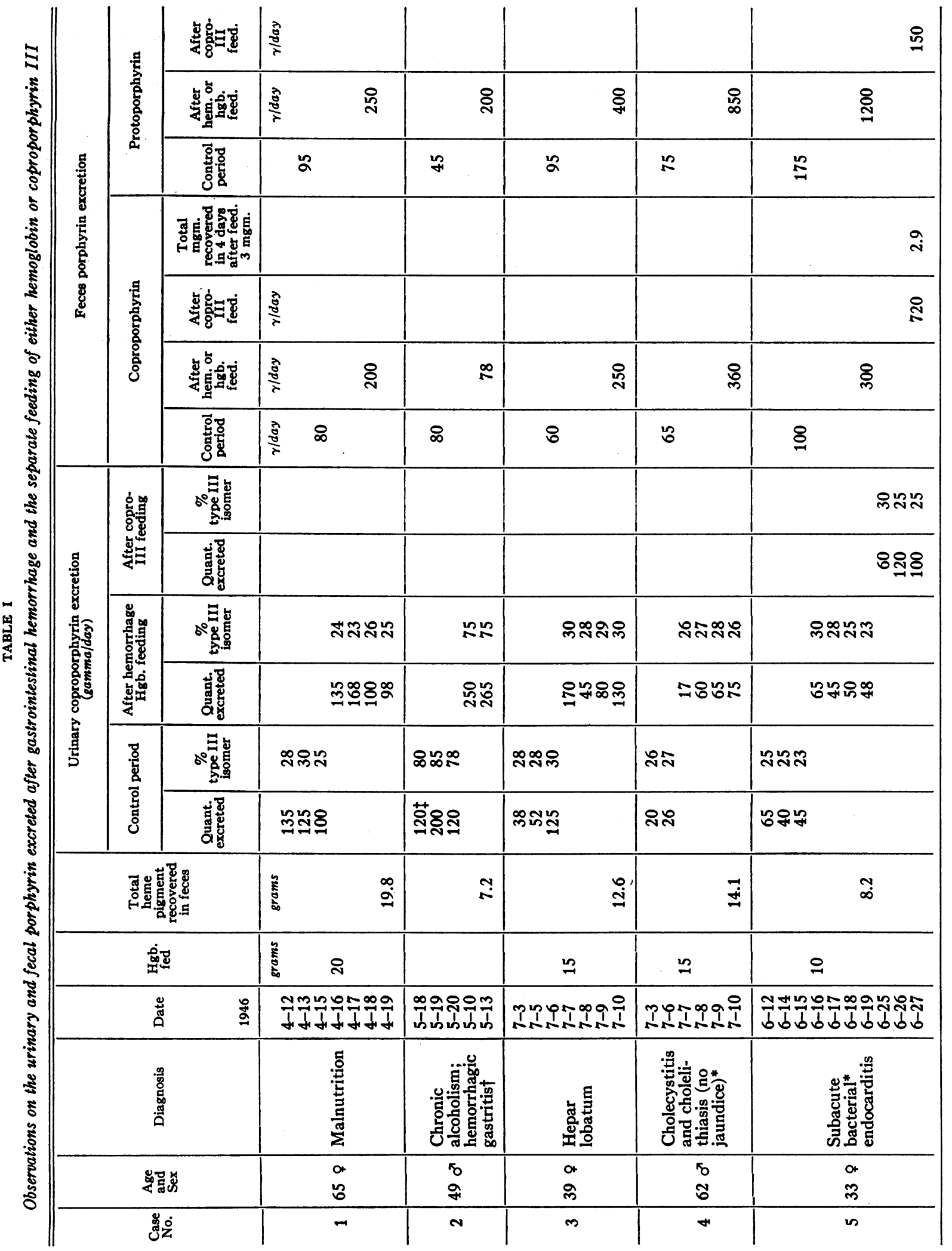


STUDIES OF COPROPORPHYRIN. II.

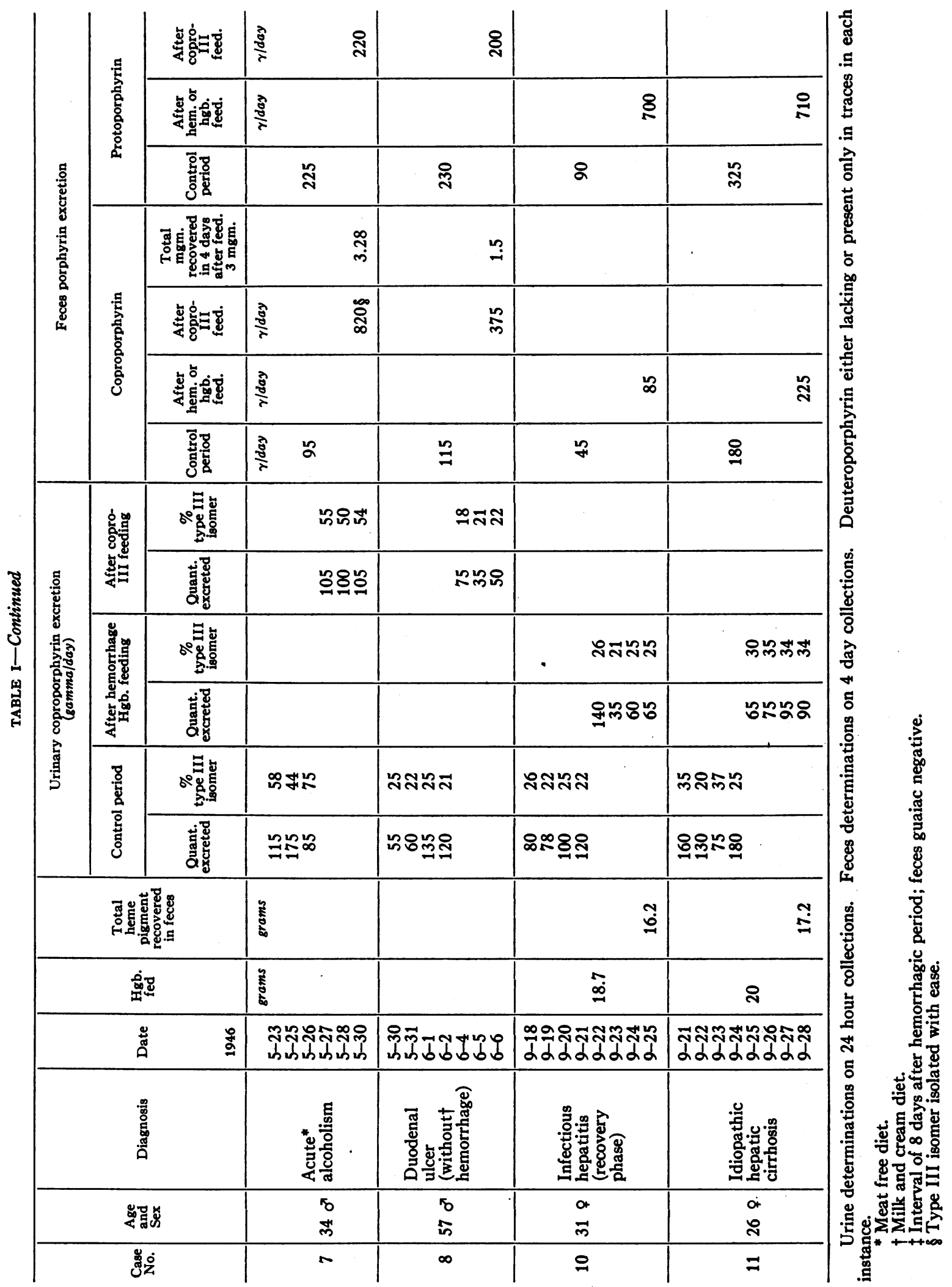


TABLE II

Observations on the bacterial synthesis of porphyrins

\begin{tabular}{|c|c|c|c|c|c|}
\hline Organism & $\begin{array}{l}\text { Culture } \\
\text { medium }\end{array}$ & $\begin{array}{c}\text { Days } \\
\text { cul- } \\
\text { tured }\end{array}$ & $\begin{array}{c}\text { Type } \\
\text { por- } \\
\text { phyrin }\end{array}$ & $\underset{\text { in }}{\text { Amount }}$ & Isomers \\
\hline \multirow{2}{*}{ B. coli $\dagger$} & $\begin{array}{l}\text { Plain } \\
\text { Broth }\end{array}$ & 15 & $\begin{array}{l}\text { Copro- } \\
\text { Proto- } \\
\text { Deutero- }\end{array}$ & $\begin{array}{l}35 / 500 \text { cc. } \\
\text { Trace } \\
\text { Neg. }\end{array}$ & $\begin{aligned} \mathrm{I} & =15 \% \\
\mathrm{III} & =\mathbf{8 5 \%}\end{aligned}$ \\
\hline & $\begin{array}{l}\text { Blood } \\
\text { Broth }\end{array}$ & 15 & $\begin{array}{l}\text { Copro- } \\
\text { Proto- } \\
\text { Deutero- }\end{array}$ & $\begin{array}{l}15 / 500 \text { cc.* } \\
\text { Trace } \\
\text { Neg. }\end{array}$ & $\begin{aligned} \mathrm{I} & =9 \% \\
\mathrm{III} & =91 \%\end{aligned}$ \\
\hline \multirow{2}{*}{$\begin{array}{l}\text { Aerobacter } \\
\text { aerogenes } \dagger\end{array}$} & $\begin{array}{l}\text { Plain } \\
\text { Broth }\end{array}$ & 14 & $\begin{array}{l}\text { Copro- } \\
\text { Proto- } \\
\text { Deutero- }\end{array}$ & $\begin{array}{l}38 / 500 \mathrm{cc} . \\
7 / 500 \mathrm{cc} . \\
\mathrm{Neg} .\end{array}$ & $\begin{aligned} \mathrm{I} & =14 \% \\
\mathrm{II} & =86 \%\end{aligned}$ \\
\hline & $\begin{array}{l}\text { Blood } \\
\text { Broth }\end{array}$ & 14 & $\begin{array}{l}\text { Copro- } \\
\text { Proto- } \\
\text { Deutero- }\end{array}$ & $\begin{array}{l}34 / 500 \mathrm{cc} . \\
16 / 500 \mathrm{cc} . \\
\mathrm{Neg} .\end{array}$ & $\begin{aligned} \mathrm{I} & =\mathbf{1 1 \%} \\
\mathrm{III} & =89 \%\end{aligned}$ \\
\hline \multirow{2}{*}{$\begin{array}{l}\begin{array}{l}\text { Pseudomonas } \\
\text { aeruginosa }\end{array}\end{array}$} & $\begin{array}{l}\text { Tryptose } \\
\text { Broth } \\
\end{array}$ & 12 & $\begin{array}{l}\text { Copro- } \\
\text { Proto- } \\
\text { Deutero- } \\
\end{array}$ & $\begin{array}{l}31 / 100 \mathrm{cc} . \\
28 / 100 \mathrm{cc} . \\
\mathrm{Neg} .\end{array}$ & $\begin{aligned} \mathrm{I} & =27 \% \\
\text { III } & =73 \%\end{aligned}$ \\
\hline & $\begin{array}{l}\text { Tryptose } \\
\text { Blood } \\
\text { Broth }\end{array}$ & 12 & $\begin{array}{l}\text { Copro- } \\
\text { Proto- } \\
\text { Deutero- }\end{array}$ & $\begin{array}{l}42 / 100 \text { cc. } \\
38 / 100 \text { cc. } \\
\text { Neg. }\end{array}$ & $\begin{aligned} \text { I } & =17 \% \\
\text { III } & =83 \%\end{aligned}$ \\
\hline Feces & Synthetic & 11 & None & None/500 cc. & \\
\hline $\begin{array}{l}\text { Pseudomonas } \\
\text { aeruginosa } \dagger\end{array}$ & Synthetic & 11 & None & None/500 cc. & \\
\hline $\begin{array}{l}\text { Pseudomonas } \\
\text { aeruginosa } \dagger\end{array}$ & Synthetic & 11 & None & None/500 cc. & \\
\hline
\end{tabular}

Heme compounds not demonstrable in $200 \mathrm{cc}$. of plain broth after extraction and eight-fold concentration (40).

* An estimated half of the total porphyrin lost during extraction.

$\dagger$ Inoculated organism recovered in pure culture at end of experiment.

The increases in UCP observed in the cases of alcoholism included in the present study, are consistent with the usual finding in acute alcoholism of distinct increases of coproporphyrin III, sufficient as a rule to elevate the UCP value into the range of $120-500 y /$ day. This will be considered in detail in a subsequent paper of this series. The regular increases in alcoholics not having blood in the intestinal tract, obviate the need of ascribing to such a source the increase observed in the cases of hemorrhagic (alcoholic) gastritis included in the present study.

Previous investigators $(3,6)$ have utilized a diet low in protoporphyrin content as a prerequisite to the demonstration of reabsorption of porphyrin from the bowel after the feeding of blood or porphyrin. Wherever it was feasible clinically, this plan was followed in the present investigation, in spite of which, the results in the studies on humans do not indicate any differences in urinary porphyrin excretion which might be attributed to the diet.

Just as in the dog experiments, increases of fecal coproporphyrin excretion were almost in- variably observed following the feeding of blood to humans. One notable exception occurred in the case of high-grade biliary obstruction (Figure 6) which suggests that the elevations in the other instances were on the basis of increased flow of bile into the intestine. However, an alteration of the bacterial flora and consequently of bacterial synthesis of porphyrin, due to the exclusion of bile from the intestine, cannot be excluded. In this connection, it is of interest that preliminary studies have failed to reveal any effect of aureomycin, given orally, on the UCP. It is known that aureomycin markedly inhibits the bacterial flora of the colon, especially $E$. coli.

In the studies on bacteria, pure cultures of several organisms in broth media were found capable of synthesizing both coproporphyrin and protoporphyrin. In contrast to the results of previous studies $(17,18)$, relatively little protoporphyrin was recovered from the culture of $E$. coli in a medium containing blood. The explanation may lie in the much larger amount of hemoglobin which was exposed to bacterial action in the previous studies; it is also possible that the longer period of culture in the present study resulted in degradation and disappearance of an undetermined fraction of the protoporphyrin. The synthesis progressed despite the absence of demonstrable heme compounds, lending support to recent tracer studies which indicate that this process proceeds from simple precursor molecules such as acetate and glycine $(41,42)$.

\section{SUMMARY AND CONCLUSIONS}

1. Studies in dogs have shown that a milk diet is associated with a higher urinary and lower fecal coproporphyrin excretion than a diet composed of milk and prepared (kibbled) dog food. The total amount of coproporphyrin excreted is approximately the same, and the interpretation is favored that the hepatic coproporphyrin excretory function or the bile flow, or both, are relatively diminished on a milk diet.

2. No evidence was obtained either in dogs or humans, with normal or impaired liver function, of an absorption of coproporphyrin from the intestine and excretion in the urine, following the feeding of blood or raw meat, or spontaneous gastrointestinal hemorrhage. Increases were commonly encountered in the feces in such experi- 
ments, but in instances where the porphyrin was identified it was shown to be the type I rather than the type III isomer.

3. No evidence was obtained in human experiments for the absorption from the intestine and excretion in the urine of fed coproporphyrin I or III. This was true in individuals with markedly impaired as well as normal liver function. The bulk of the fed porphyrin was recovered in the feces. Any small fractions that may have been absorbed were either metabolized or reexcreted in the bile.

4. A variety of bacterial strains, in pure culture, were found to. synthesize both protoporphyrin 9 (type III) and coproporphyrin III. This synthesis did not proceed on artificial media of the Gladstone type, but required substances, presumably of protein character or origin, present in broth. The synthesis of porphyrins proceeded in broth media which did not contain demonstrable hemoglobin or heme pigments.

\section{BIBLIOGRAPHY}

1. Stokvis, B. J., Zur Pathogenese der Hämatoporphyrinurie. Ztschr. f. klin. Med., 1895, 28, 1.

2. Schumm, O., Utber die natürlichen Porphyrine. I. Das in Harn Gesunder gefundene Porphyrin. Ztschr. f. physiol. Chem., 1923, 126, 169.

3. Fischer, Hans, and Hilmer, H., Uber KoproporphyrinSynthese durch Hefe und ihre Beeinflüssung. IV. Ztschr. f. physiol. Chem., 1926, 153, 167.

4. Brugsch, J. T., Untersuchungen des quantitativen Porphyrinstoff wechsels beim gesunden und kranken Menschen. I. Der normale Porphyrinstoff wechsel. Ztschr. f. d. ges. exper. Med., 1935, 95, 471.

5. Brugsch, J. T., Ibid. II. Der Porphyrinstoff wechsel bei Anämien, sowie bei Blut- und Gewebszerfall. Ztschr. f. d. ges. exper. Med., 1935, 95, 482.

6. Kaunitz, H., Uber Porphyrinurie nach Hämoglobinbelastung. Ztschr. f. klin. Med., 1938, 133, 552.

7. Garrod, A. E., The Bradshaw lecture on the urinary pigments in their pathological aspects. Lancet, 1900, 2, 1323.

8. Günther, H., Die bedeutung der Hämatoporphyrine in Physiologie und Pathologie. Ergebn. d. allg. path. Anat., 1922, 20, 608.

9. Waldenström, J., Bemerkungen zu der Arbeit von E. Mertens, Uber das Uroporphyrin usw. Ztschr. f. physiol. Chem., 239, Supp. III, 1936.

10. Dobriner, K., and Rhoads, C. P., The porphyrins in health and disease. Physiol. Rev., 1940, 20, 416.

11. Watson, C. J., and Larson, E. A., The urinary coproporphyrins in health and disease. Physiol. Rev., 1947, 27, 478.
12. Jakob, A., Über den Abbau von Blutfarbstoff zu Porphyrinen durch Reinkulturen von Bakterien und über eine neue biologische Synthese von Koproporphyrin III. Klin. Wchnschr., 1939, 18, 1024.

13. Snapper, I., Enterogenes Entstehen von Porphyrinen aus Blutfarbstoff. Arch. f. Verdauungskr., 1919, 25, 230.

14. Snapper, I., Die Bildung von Porphyrinen in Darmkanal. Berlin. klin. Wchnschr., 1921, 58, 800.

15. Snapper, I., and van Creveld, S., Uber okkulte Blutungen. Ergebn. d. inn. Med. u. Kinderh., 1927, 32, 1.

16. Kämmerer, H., Bacterien und Blutfarbstoff. Arch. f. exper. Path. u. Pharmakol., 1920, 88, 247.

17. Hill, R., and Holden, H. F., The preparation and some properties of the globin of oxyhaemoglobin. Biochem. J., 1926, 20, 1326.

18. van den Bergh, A. A. H., Grotepass, W., and Revers, F. E., Beitrag über das Porphyrin in Blut und Galle. Klin. Wchnschr., 1932, 11, 1534.

19. Watson, C. J., Concerning the naturally occurring porphyrins. V. Porphyrins of the feces. J. Clin. Invest., 1937, 16, 383.

20. Fischer, H., and Hilger, J., Zur Kenntnis der natürlichen Porphyrine. $\mathrm{X}$. Uber Blutfarbstoff im der Hefe; Nachweis von Porphyrin in Pflanzen. Ztschr. f. physiol. Chem., 1924, 138, 289.

21. Kench, J. E., and Wilkinson, J. F., Porphyrin formation by yeast. Nature, 1945, 155, 579.

22. Coulter, C. B., and Stone, F. M., The occurrence of porphyrins in cultures of C. diphtheriae. J. Gen. Physiol., 1930, 14, 583.

23. Gray, C. H., and Holt, L. B., The porphyrin produced by diphtheria bacillus. J. Biol. Chem., 1947, 169, 235.

24. von Mallinkrodt-Haupt, A. S., Ursache und Bedeutung des Koproporphyrin I im Menschlichen Organismus. Klin. Wchnschr., 1941, 20, 190.

25. Boas, I., Die Porphyrine und ihre Bedeutung für die Verdauungspathologie. Deutsche med. Wchnschr., 1933, 59, 126.

26. Boas, I., Uber die Unterscheidung benigner vom malignen Blutungen des Magendarmkanals. Deutsche med. Wchnschr., 1935, 61, 2003.

27. Brugsch, J. T., Ibid. III. Die sekundären Störungen des Porphyrinstoff wechsels. Ergebn. d. inn. Med. u. Kinderh., 1936, 51, 86.

28. Dobriner, K., The urinary porphyrins in disease. J. Biol. Chem., 1936, 113, 1.

29. Nesbitt, S., and Snell, A. M., Excretion of coproporphyrin in hepatic disease; correlation of urinary and fecal excretion with parenchymatous hepatic damage. Arch. Int. Med., 1942, 69, 573.

30. Tropp, E., and Seigler, K., Quantitative klinische Harnporphyrinuntersuchungen; 1. Der normale Harnporphyrinstoff wechsel. Deutsches Arch. f. klin. Med., 1937, 180, 402.

31. Zeligman, I., Urinary excretion of porphyrin in dermatoses. Arch. Dermat. \& Syph., 1946, 54, 281. 
32. Borst, M., and Königsdorffer, H., Jr., Untersuchungen über Porphyrie mit besonderer Berücksichtigung der porphyria congenita. S. Hirzel, Leipzig, 1929, p. 219.

33. Schwartz, S., Hawkinson, V., Cohen, S., and Watson, C. J., A micromethod for the quantitative determination of the urinary coproporphyrin isomers (I and III). J. Biol. Chem., 1947, 168, 133.

34. Watson, C. J., and Layne, J. A., Studies of urinary pigments in pellagra and other pathological states; clinical observations. Ann. Int. Med., 1943, 19, 183.

35. Watson, C. J., Studies of urobilinogen. I. An improved method for the quantitative estimation of urobilinogen in urine and feces. Am. J. Clin. Path., 1936, 6, 458.

36. Terwen, A. J. L., Ueber ein neues Verfahren zur quantitativen Urobilin Bestimmung im Harn und Stuhl. Deutsches Arch. f. klin. Med., 1925, 149, 72.

37. Watson, C. J., Concerning the naturally occurring porphyrins. I. The isolation of coproporphyrin I from the urine in a case of cincophen cirrhosis. J. Clin. Invest., 1935, 14, 106.
38. Grinstein, M., Schwartz, S., and Watson, C. J., Studies of the uroporphyrins; the purification of uroporphyrin I and the nature of Waldenström's uroporphyrin, as isolated from porphyria material. J. Biol. Chem., 1945, 157, 323.

39. Watson, C. J., Schwartz, S., and Hawkinson, V., Studies of the uroporphyrins; further studies of the porphyrins of the urine, feces, bile, and liver in cases of porphyria, with particular reference to a Waldenström type porphyrin behaving as an entity on the Tswett column. J. Biol. Chem., 1945, $157,345$.

40. Flink, E. B., and Watson, C. J., A method for the quantitative determination of hemoglobin and related heme pigments in feces, urine, and blood plasma. J. Biol. Chem., 1942, 146, 171.

41. Bloch, K., and Rittenberg, D., An estimation of acetic acid formation in the rat. J. Biol. Chem., 1945, 159, 45.

42. Shemin, D., and Rittenberg, D., The biological utilization of glycine for the synthesis of the protoporphyrin of hemoglobin. J. Biol. Chem., 1946, 166, 621 . 